efficiency at the rate of $200 \mathrm{kcal} / \mathrm{day}$, it would last for about 5 months. The loss in body-weight by lactating women confirms that such utilization of reserves does, in fact, occur (Hytten \& Thomson, 196r). But breast-feeding is becoming the exception rather than the rule in Western society and, if it is not removed by lactation or exercise, the surplus of fat may represent the beginnings of obesity. We may therefore have to revise our ideas of 'normality' in the light of the customs in modern urban society.

\title{
REFERENCES
}

Boyne, A. W., Chalmers, M. I. \& Cuthbertson, D. P. (1953). Hoppe-Seyl. Z. 295, 424.

Burwell, C. S. (1954). Fohns Hopk. Hosp. Bull. 95, x 15.

FAO: Second Committee on Calorie Requirements. (1957). FAO nutr. Stud. no. I 5.

Hytten, F. E. \& Thomson, A. M. (1961). In Milk : the Mammary Gland and its Secretion, Vol, 2, Ch. 13. [S. K. Kon and A. T. Cowie, editors.] New York and London: Academic Press Inc.

Kelly, H. J., Sloan, R. E., Hoffman, W. \& Saunders, C. (I95I). Hum. Biol. 23, 6r.

Kosterlitz, H. W. \& Campbell, R. M. (1957). Ann. Nutr. Aliment. Ix, A 85.

Morrison, S. D. (1956). F. Physiol. 134, 650.

National Research Council: Food and Nutrition Board. (1958). Publ. nat. Res. Coun., Wash., no. 589.

Romney, S. L., Reid, D. E., Metcalfe, J. \& Burwell, C. S. (1955). Amer. F. Obstet. Gynec. 70, 79 I.

Sandiford, I., Wheeler, T. \& Boothby, W. M. (1931). Amer. F. Physiol. 96, г91.

Spray, C. M. (1950). Brit. F. Nutr. 4, 354.

Taggart, N. R. (1961). Proc. Nutr. Soc. 20, 35.

Thomson, A. M. \& Billewicz, W. Z. (1957). Brit. med. f. i, 243.

Thomson, A. M. \& Hytten, F. E. (1960). Proc. Nutr. Soc. 19, 5.

Widdowson; E. M. \& Spray, C. M. (195r). Arch. Dis. Childh. 26, 205.

\section{Energy balance in early life}

\section{By Elsie M. Widdowson, Medical Research Council Department of Experimental Medicine, University of Cambridge}

When a baby has safely come through the strenuous hazards of being born, starvation immediately confronts it for anything up to 5 days. While in the uterus the foetus receives a constant supply of food materials from its mother through the placenta, but as soon as the cord is tied this supply of nourishment is suddenly cut off. In many mammals suckling begins almost immediately, but not so in man. If the baby is the firstborn there is rarely any significant amount of colostrum for at least $24 \mathrm{~h}$, and if the baby is premature, or if birth has been difficult and the baby is distressed, it is likely to be kept without food for a much longer time. We all start life in negative energy balance. The baby katabolizes some of its own body tissue to provide the energy it requires, and it consequently loses weight. The loss of weight is partly of water, partly of solid matter; how much solid matter is lost per day depends upon the metabolic rate and upon the proportions of protein, fat and carbohydrate that are being oxidized.

Many mammals are born with a high concentration of glycogen in their livers and sometimes also in their skeletal muscles (Goldwater \& Stetten, 1947; McCance \& Widdowson, I959; Shelley, r960). There seems to be no information about the baby at term, but the human foetus at the 20 th week of gestation already has $4 \%$ of 
glycogen in its liver (Villee, 1953), and it can be deduced from the respiratory quotient that for some hours after birth the starving newborn baby is deriving about two-thirds of its energy from its glycogen stores. As these get used up it turns over to the oxidation of fat, and by the end of the Ist day of starvation at least two-thirds of its energy is coming from this source (Table I; see Smith, I959). The respiratory

Table I. Respiratory quotient, and percentage of its total energy requirements obtained from carbohydrate and fat by the newborn baby (Smith, r959)

\begin{tabular}{|c|c|c|c|}
\hline Time after birth & $\begin{array}{l}\text { Respiratory } \\
\text { quotient }\end{array}$ & $\begin{array}{l}\text { alories obtaine } \\
\text { from } \\
\text { carbohydrate }\end{array}$ & $\begin{array}{c}\text { Calories obtained } \\
\text { from fat }\end{array}$ \\
\hline Few hours, starving & 0.90 & 66 & 34 \\
\hline Day I, starving & 0.80 & 30 & 70 \\
\hline Day 2 , starving & 0.75 & 8 & 92 \\
\hline Day 3 , starving & 0.74 & 5 & 95 \\
\hline Day 4 , feeding begun & 0.76 & 12 & 88 \\
\hline Day 5 , more food taken & 0.79 & 26 & 74 \\
\hline Day 6 onwards, feeding established & 0.82 & 34 & 66 \\
\hline
\end{tabular}

About $4 \%$ of the total energy is derived from protein, but it has been neglected in calculating the above values.

quotient falls steadily for the first 3 days if the baby is unfed (Cross, Tizard \& Trythall, 1957), and on the 2nd and 3 rd days over $90 \%$ of the calories are derived from fat. Protein can almost be neglected, for it provides only $4 \%$ of the starving newborn baby's calories, in contrast to $20 \%$ of the starving adult's (McCance \& Strangeways, 1954). This is a manifestation of the anabolic tendency of the newborn baby even when it is starving and therefore unable to grow.

In considering the metabolic rate of a baby we at once come up against two difficulties. The first is how to express the results so that they mean something in terms of the adult. Should we, for example, compare the baby with the adult per unit of surface area or per unit of body-weight? It makes a great difference to the results which we choose, for a baby of $3.5 \mathrm{~kg}$ weighs one-twentieth as much as a $70 \mathrm{~kg}$ man, but his surface area is only one-eighth of that of the man. Smaller bodies have relatively greater surface areas than large ones, and they therefore cool more quickly in surroundings below their body temperature. Basal metabolic rates are always more nearly proportional to surface area than to body-weight, which is seen from Table 2 where the basal metabolic rates of a premature and full-term newborn

Table 2. Basal metabolism of newborn infants and adults (Smith, 1959)

\begin{tabular}{lcc}
\multicolumn{1}{c}{ Subject } & $\mathrm{kcal} / \mathrm{m}^{2} \mathrm{~h}$ & $\mathrm{kcal} / \mathrm{kg} \mathrm{h}$ \\
Premature infant & $26 \cdot 3$ & $2 \cdot 04$ \\
Full-term infant & $29 \cdot 2$ & $2 \cdot 00$ \\
Adult & $35-40$ & $\mathrm{I} \cdot 00$
\end{tabular}

baby are compared with that of an adult, both per $\mathrm{m}^{2}$ of surface area and per $\mathrm{kg}$ of body-weight. The metabolic rate of the full-term baby is slightly lower than that of the adult per $\mathrm{m}^{2}$, but per $\mathrm{kg}$ it is twice as high. We know that the newborn baby or 
animal has a higher percentage of water in its body than the adult, and it has a smaller cell mass per unit of body-weight. Its cells, therefore, must be metabolizing much faster than those of an adult, but how it is brought about at cellular level has not yet been discovered.

The second difficulty concerning the baby's metabolic rate is the environmental temperature, for it affects heat production (McCance, 1959). For every animal there is a range of environmental temperature, called the zone of thermal neutrality, at which the basal metabolic rate is at its lowest. In this range of temperature the animal is able to maintain a normal body temperature with the least possible expenditure of energy. Departure from it in either direction raises the metabolic rate. If the environmental temperature falls below the lower limit of the range, i.e. the critical temperature, the metabolic rate goes up, which helps to prevent a fall in body temperature. If the environmental temperature rises above the upper limit, the metabolic rate begins to go up for reasons not fully understood, but restlessness is probably involved; this in turn leads to a rise in deep body temperature, which causes a further increase in metabolic rate due to an increase in the rate of cellular metabolism. The critical temperature varies with age, and is considerably higher soon after birth than it is later in life. In adult man it is about $28^{\circ}$ in air, in newborn babies it is $32-35^{\circ}$ (Brück, Brück \& Lemtis, I 958).

The foetus does not have any problems about environmental temperature, for it lives comfortably at $37^{\circ}$ and is never exposed to cold surroundings. It has been estimated that the oxygen consumption of the human foetus near term is about $5 \mathrm{ml} /$ $\mathrm{kg}$ min (Romney, Reid, Metcalfe \& Burwell, 1955). On the assumption that this oxygen is all used for the oxidation of carbohydrate, the energy equivalent amounts

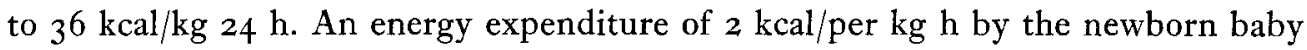
(Table 2) is equal to $48 \mathrm{kcal} / \mathrm{kg} 24 \mathrm{~h}$, and $40-50 \mathrm{kcal}$ is about the value that all workers have obtained for the basal metabolism of the starving newborn infant (Benedict \& Talbot, 1915; Karlberg, I952; McCance \& Strangeways, 1954; Cross et al. I957). Thus, there appears to be a rise in oxygen consumption immediately after birth, which is in line with observations on the lamb (Dawes \& Mott, 1959). This rise in oxygen consumption is almost certainly a response to the fall in body temperature which begins to take place when the foetus comes out of the warm uterus into the comparatively cold world outside. The newborn baby does constrict its peripheral vessels in response to a low ambient temperature (Brück et al. I957, I958), but control of heat loss seems relatively unimportant in regulating the internal body temperature of the newly born. From the moment it is born the baby has the ability to raise its heat production and metabolic rate when the environmental temperature is below the critical temperature, and this is the main way in which it controls its internal body temperature. In the first few hours and days of life this ability materially improves. This statement is true, not only for the human baby (Cross et al. I957; Brück et al. 1957) but also for the lamb and monkey (Dawes, Jacobson, Mott \& Shelley, I960) and for the pig (Mount, I959). The values obtained by Cross et al. for the basal metabolic rates of individual full-term babies aged o-9 days are shown in Fig. I. In spite of the rather wide scatter between individual 
babies (see p. 88) the rise in basal metabolic rate over the first 3 days is statistically significant.

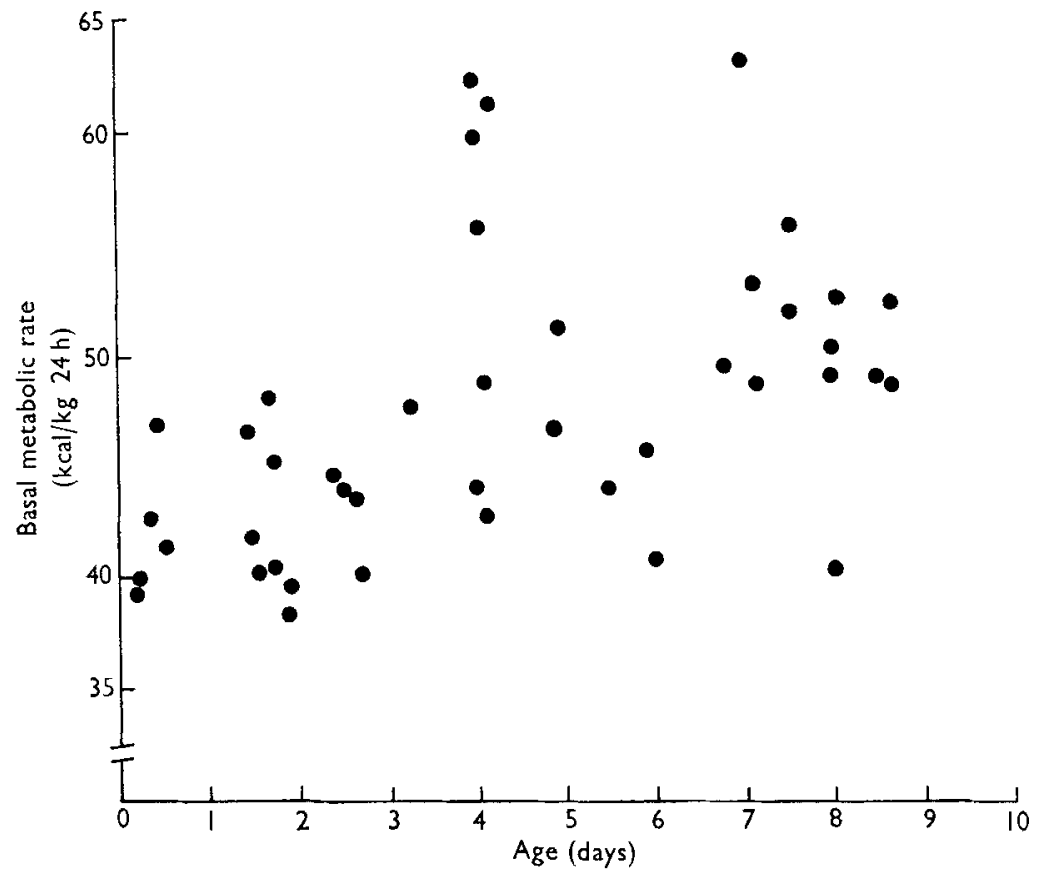

Fig. I. Basal metabolic rate of full-term babies 0-9 days old (values of Cross et al. 1957).

The increase in heat production in response to a low environmental temperature takes place without apparent shivering, unless the body temperature falls to very low levels, and most people have thought that it takes place without any great increase in physical activity. However, Mestyán \& Varga (1960) have recently studied the effect of environmental temperature on the oxygen consumption of full-term and premature newborn babies, and they believe that most of the increase in heat production of the newborn baby as the environmental temperature falls is due to an increase in visible activity. One baby, weighing $2.8 \mathrm{~kg}$, for example, was sleeping peacefully in an environmental temperature of $32^{\circ}$ and its oxygen consumption was I $20 \mathrm{ml} / \mathrm{r} \cdot 73 \mathrm{~m}^{2} \mathrm{~h}$. The environmental temperature was then reduced to $22^{\circ}$. The baby slept for a few minutes, and then woke up and its body temperature began to fall and it became very restless. The oxygen consumption increased to $190 \mathrm{ml} / \mathrm{s} \cdot 73$ $\mathrm{m}^{2} \mathrm{~h}$, and the rise in metabolic rate brought the body temperature back to normal. The environmental temperature was then slowly raised to $32^{\circ}$ again. The baby gradually became quieter and finally fell asleep, and the oxygen consumption decreased to its original basal level. Mestyán \& Varga believe that increased muscular activity in response to cold is largely responsible for the rise in metabolic rate. The high metabolic rate in cold surroundings uses up the readily available sources of energy in the body more rapidly than if the baby or animal is kept warm, and the 
blood sugar may fall to very low levels (Mann \& Elliott, 1957; Goodwin, 1957; McCance \& Widdowson, 1959).

For several reasons the premature baby is more vulnerable to cold than one born at full term. In warm surroundings it has about the same basal metabolic rate per $\mathrm{kg}$ as the full-term baby (Cross et al. 1957; and see Table 2), but its cooling surface is relatively greater so that its basal metabolic rate per unit of surface is lower (Table 2). Moreover, it does not have the insulating layer of fat that surrounds the full-term baby. Its metabolic rate rises in response to cold, but it must rise more to maintain a normal body temperature at the same low environmental temperature. Silverman, Fertig \& Berger ( $\left.195^{8}\right)$ have studied the survival rate of matched pairs of premature babies over the first 5 days of life, the one group at an environmental temperature of $3 \times 7^{\circ}$, the other at $28 \cdot 9^{\circ}$, and Table 3 sets out their results. The table speaks for itself.

Table 3. Survival rate of premature babies at two environmental temperatures (Silverman, Fertig \& Berger, 1958)

Body-weight
(kg)
$>1 \cdot 5$
$\mathrm{I} \cdot 0-\mathrm{x} \cdot 5$
$<\mathrm{x} \cdot 0$

\begin{tabular}{ccc} 
& \multicolumn{2}{c}{ Survival rate $(\%)$ at } \\
No. of infants & $31.7^{\circ}$ & $\mathbf{2 8 . 9 ^ { \circ }}$ \\
84 & 92.9 & 78.6 \\
70 & 85.7 & 77.1 \\
28 & 50.0 & 14.3
\end{tabular}

Crying increases the metabolic rate, sometimes to three or four times the basal level (Cross et al. 1957), so a baby that cries a great deal will have a higher energy expenditure and lose more weight while it is starving than one which spends nearly all its time sleeping. Respiratory distress also increases the metabolic rate, and distressed babies have been shown to lose twice as much weight during the first days of life as normal babies.

Now let us turn to a happier time in the life of the baby, when it is getting some food. By the end of the Ist week there should be a good milk supply, and the baby should be able to take its fill of breast milk five or six times a day. The heat of combustion of breast milk at this stage of lactation is $78 \mathrm{kcal} / \mathrm{ro0} \mathrm{ml}$. Thirteen breastfed babies that we have studied recently on the 6th, 7 th and 8th days of life took an average of $\mathrm{I} 20 \mathrm{ml}$ breast milk/kg body-weight daily (Slater, $196 \mathrm{I}$ ), so that their gross energy intake was $94 \mathrm{kcal} / \mathrm{kg}$ day. Table 4 shows the energy balance of these babies, compared with that of bottle-fed babies receiving a mixture of cow's full-cream

Table 4. Energy balance (kcal/kg body-weight $24 h$ ) of babies $\mathrm{I}$ week old and of adults

Gross calorie intake

Calories lost in faeces

Calories lost in urine

Calories available for maintenance and growth

Nitrogen retained: $g$

calorific value (as protein)

Calories available for maintenance

Breast-fed
babies
94
4
1
89
0.21
8
81

Bottle-fed
babies
I03
5
2
96
0.29
10
86

Adults 
milk and lactose and of adults on a normal mixed diet. The calorie intakes of the babies were more than twice as high as those of the adults per $\mathrm{kg}$ body-weight, and they were considerably above the requirement for basal metabolism. The loss of calorific material in the faeces amounted to $4-5 \%$ of the intake in all three groups, and the loss in the urine due to the urea, creatinine and other oxidizable end-products of protein katabolism to another $\mathrm{I}$ or $2 \mathrm{kcal}$. The number of calories remaining for energy metabolism and, with the babies, for growth amounted to 89,96 and $39 / \mathrm{kg}$ day for breast and bottle-fed babies and adults respectively. The breast-fed and bottle-fed babies retained $0.2 \mathrm{I}$ and $0.29 \mathrm{~g}$ nitrogen $/ \mathrm{kg}$ day for purposes of growth. Some energy is required to synthesize tissue protein from the amino acids absorbed, but it can only be very small in amount and, if it is neglected for the present purpose, the calorific value of the protein corresponding to the nitrogen retained amounted to 8 and ro $\mathrm{kcal} / \mathrm{kg}$ day for breast-fed and bottle-fed babies. Some fat may also be laid down, but we have no accurate measure of it, and in fact the gain in weight of the babies over the period of observation was accounted for almost exactly by the nitrogen retained. It is evident, therefore that only a small proportion of the baby's total calorie intake is used for purposes of growth, even at this stage of postnatal life when the growth rate is probably higher than it ever is again. About $90 \%$ of the energy value of the food is used to maintain the living structure of the body and a normal body temperature.

All that has been said so far has concerned mean values. What about the individual baby? How much do energy requirements vary from one baby to another? It has become clear in the past few years that the basal metabolism of adults varies from one person to another much more widely than was generally supposed (Edholm, Fletcher, Widdowson \& McCance, I955; Booyens \& McCance, I957; Richardson \& McCracken, 1960) and that this goes a long way towards explaining the big differences in calorie intakes and total energy expenditures of different individuals. Although there is a general trend upward in the basal metabolic rate of babies in the first days after birth (Fig. I), there is undoubtedly a wide variation from one baby to another. One baby aged 4 days for example was expending $62 \mathrm{kcal} / \mathrm{kg}$ day, another only $43 \mathrm{kcal}$, which is a difference of nearly $50 \%$. In the group of twenty-two adults studied by Booyens \& McCance the highest energy expenditure on basal metabolism amounted to $29 \mathrm{kcal} / \mathrm{kg} 24 \mathrm{~h}$, and the lowest to $\mathrm{r} 8 \mathrm{kcal}$, a difference of about $60 \%$. We do not know whether the baby with a basal metabolic rate much below the average will become the adult with a very low value, but there is no reason to suppose he will not, and the evidence goes to show that the older child who eats less than the average on one occasion will probably still be eating less than the average several years later (Widdowson, 1947). When other variables which increase the calorie requirement of babies are also taken into account, for instance crying and exposure to cool surroundings, it seems quite unphysiological to expect all babies to require exactly the same amount of food, even if reckoned per $\mathrm{lb}$ or per $\mathrm{kg}$ of body-weight. Studies that have been made comparing the progress of babies allowed to feed 'on demand' with that of others fed to a strict schedule leave no doubt that some babies are ready to take more food than the usual ration and grow faster if they are allowed to have it 
(Faber, 1922; Hardy \& Goldstein, 195 $\mathrm{x}$ ). Whether it is a good or bad thing is quite another story.

\section{REFERENCES}

Benedict, F. G. \& Talbot, F. B. (I 915). Publ. Carneg. Instn, no. 233.

Booyens, J. \& McCance, R. A. (1957). Lancet, 272, 225.

Brück, K., Brück, M. \& Lemtis, H. (1957). Pfiüg. Arch. ges. Physiol. 265, 55.

Brück, K., Brück, M. \& Lemtis, H. (1958). Pflüg. Arch. ges. Physiol. 267, 382.

Cross, K. W., Tizard, J. P. M. \& Trythall, D. A. H. (1 957). Acta Paediat., Stockh., 46, 265.

Dawes, G. S., Jacobson, H. N., Mott, J. C. \& Shelley, H. J. (1960). F. Physiol. r52, 27 I.

Dawes, G. S. \& Mott, J. C. (1959). F. Physiol. 146, 295.

Edholm, O. G., Fletcher, J. G., Widdowson, E. M. \& McCance, R. A. (1955). Brit. F. Nutr. 9, 286.

Faber, H. K. (1922). Amer. F. Dis. Child. 24, 56.

Goldwater, W. A. \& Stetten, De W. (1947). F. biol. Chem. 169, 723.

Goodwin, R. F. W. (1957). F. Physiol. 136, 208.

Hardy, J. B. \& Goldstein, E. O. (195 I). F. Pediat. 38, I54.

Karlberg, P. (1952). Acta Paediat., Stockh., 4r, Suppl. 89.

McCance, R. A. (1959). Arch. Dis. Childh. 34, 459.

McCance, R. A. \& Strangeways, W. M. B. (r954). Brit. F. Nutr. 8, 2 I.

McCance, R. A. \& Widdowson, E. M. (1959). F. Physiol. 147, 124.

Mann, T. P. \& Elliott, R. I. K. (1957). Lancet, i, 229.

Mestyán, G. \& Varga, F. (I960). F. Pediat. 56, 6z3.

Mount, L. E. (1959). F. Physiol. 147, 333.

Richardson, M. \& McCracken, E. C. (I 960). U.S. Dep. Agric. Home Econ. Res. Rep. no. I 1.

Romney, S. L., Reid, D. E., Metcalfe, J. \& Burwell, C. S. (1955). Amer. F. Obstet. Gynec. 70, 791.

Shelley, H. J. (1960). F. Physiol. 153, 527.

Silverman, W. A., Fertig, J. W. \& Berger, A. P. (1958). Pediatrics, Springfield, 22, 876.

Slater, J. E. (196r). Brit. $\mathcal{F}$. Nutr. 15, 83 .

Smith, C. A. (1959). The Physiology of the Newborn Infant. 3rd ed. Springfield, Ill.: C. C. Thomas.

Villee, C. A. (1953). F. appl. Physiol. 5, 437.

Widdowson, E. M. (1947). Spec. Rep. Ser. med. Res. Coun., Lond., no. 257. 